\title{
The Role of Faith-Based Organizations in Counter-Radicalization in Nigeria: The Case of Boko Haram
}

\author{
Bapak Ishaku, Sait Aksit (D) and Kangdim Dingji Maza * \\ Department of Political Science and International Relations, Near East University, Nicosia 99138, Cyprus; \\ bapakishaku@outlook.com (B.I.); sait.aksit@neu.edu.tr (S.A.) \\ * Correspondence: mdingji@gmail.com
}

check for updates

Citation: Ishaku, Bapak, Sait Aksit, and Kangdim Dingji Maza. 2021. The Role of Faith-Based Organizations in Counter-Radicalization in Nigeria: The Case of Boko Haram. Religions 12 1003. https://doi.org/10.3390/ rel12111003

Academic Editor: Jeffrey Haynes

Received: 14 September 2021

Accepted: 9 November 2021

Published: 15 November 2021

Publisher's Note: MDPI stays neutral with regard to jurisdictional claims in published maps and institutional affiliations.

Copyright: (c) 2021 by the authors. Licensee MDPI, Basel, Switzerland. This article is an open access article distributed under the terms and conditions of the Creative Commons Attribution (CC BY) license (https:/ / creativecommons.org/licenses/by/ $4.0 /)$.

\begin{abstract}
This article examines the role of faith-based organizations (FBOs) in counter-radicalization in Nigeria, with emphasis on the Boko Haram terrorist group operating in northeast Nigeria and the greater Lake Chad region. A qualitative methodological approach is employed that makes use of primary and secondary documents, key informant and stakeholder interviews, and focus group discussions with critical religious actors and organizations. The findings of the article suggest that FBOs play a critical role in the disengagement and deradicalization process of countering the ideological and radical messages of Boko Haram. However, challenges such as the lack of effective stakeholder involvement in the various initiatives by the state in counterterrorism, fear of reprisal and attacks, lack of unison by various FBOs and clerics in countering these negative messages, and the inability of relevant stakeholders in addressing structural factors such as poverty, social and economic exclusion, and unemployment that give rise to radicalization amongst other challenges, have impeded the effectiveness of the FBO sector in its counter-radicalization efforts in Nigeria. To address these challenges, the article proposes a bottom-up approach to counterterrorism that provides room for the multi-sectoral involvement of major stakeholders, especially FBOs, to complement pre-existing initiatives and other measures to counter the negative weaponization of religion by radical and rogue clerics, and also to prevent Boko Haram from expanding its frontiers.
\end{abstract}

Keywords: faith-based organizations; radicalization; Boko Haram; counter-radicalization; Nigeria; northeast region; the Lake Chad region

\section{Introduction}

Faith-based organizations (FBOs) usually play a critical role in the debates and discourse(s) regarding radicalization, counter-radicalization, violent religious extremism, and terrorism (Cozzens 2006; Rubin et al. 2011; Khalil 2012; Arshad-Ayaz and Naseem 2017). This is because scholars, experts, and policymakers often argue that the role played by FBOs in combating and taming the activities of violent extremist and terror groups in the world today cannot be overemphasized, given the fact that they serve as a moral compass for societies (Michael Kpughe 2017; El-Said and Harrigan 2018). Scholars also argue that because these violent radical and terror groups frequently instrumentalize religion negatively to perpetuate their agenda or objectives, the same approach can also be adopted to counter their negative misrepresentation of religion to radicalize individuals and groups into embracing these radical and extremist views (Maza et al. 2020). In addition, political actors and other rent-seekers who benefit from the activities of these violent radical groups use religion as a tool to advance and achieve their heinous interests (Foret and Markoviti 2020).

These narratives also apply to Boko Haram, ${ }^{1}$ a radical extremist and insurgent group that emerged over a decade ago in the northeastern part of Nigeria, as well as the Lake Chad and Sahel regions of West Africa (Maiangwa et al. 2012; Agbiboa 2013; Maza et al. 2020). Some studies have traced and linked the emergence of radicalization strategies 
and the process of this group to the negative instrumentalization of religion by religious, political, and economic elites to achieve their selfish gains (Campbell 2014; Azumah 2015; Mbah et al. 2017; Iyekekpolo 2020). Other studies claimed the failures of government to address structural problems, such as the growing unemployment, the high level of poverty in northern Nigeria, the high level school drop-outs and illiteracy in northern Nigeria, Lake Chad, and Sahel regions, and economic and social inequality, create the opportunity for groups like Boko Haram to easily exploit the vulnerabilities of the people, especially young people, to radicalize them (Adenrele 2012; Casimir et al. 2014; Ayegba 2015; Akinola 2015; Evans and Kelikume 2019). It has also been argued that technological advancement in information and communication technology, whereby the internet today has turned the world into a global village with the presence of social media and other networks such as Facebook, Twitter, YouTube, WhatsApp, etc., created the opportunity for more interaction and engagement by people across various regions. These social media platforms have also created the opportunity for violent and radical groups to easily entice and radicalize individuals into believing in their cause and joining them (Thompson 2011; Huey 2015; Van Eerten et al. 2017; Kursuncu et al. 2019). There has also been a growing portion of the literature that suggests that financial inducements, forceful conscriptions, and abductions were also used by radical groups like Boko Haram as strategies for radicalization, indoctrination, increasing their membership, and spreading the organization's propaganda (Mercy Corps 2016; Nduka 2019; Maza et al. 2020).

It is important to note that since its emergence, the group has carried out a series of attacks leading to the wanton destruction of lives, livelihoods, and properties belonging to public and private institutions in the northeastern part of Nigeria, as well as the Lake Chad and Sahel regions (Nextier SPD 2020a, 2020b). The activities of this group have further created a serious humanitarian challenge in the region, with over 2.7 million persons displaced across territories with a Boko Haram presence (UNHCR 2020).

From this informed perspective, several studies have focused on the state-centric approach prioritizing the traditional role of the state in countering the activities of this violent radical group, through the use of force or the military, while the non-military (soft and smart power) approach to counter radicalization remains largely underdeveloped (Falode 2016; Sampson 2016; Onapajo 2017; Agbiboa 2020; Martin 2020; Onapajo and Ozden 2020). It is in this context that this article will examine the role and effort of FBOs in counter-radicalization, with specific emphasis on the Boko Haram radical insurgent group. To do this, the article seeks to ask the following research questions:

- What are the roles of FBOs in counter-radicalization?

- What are the challenges facing FBOs in counter-radicalization within the Boko Haram context?

- How can these challenges be addressed?

The article is structured and organized into six sections. Following the introduction, the second section of the article outlines the methodological approach used in the study. The third part of the article provides a review of extant literature on FBOs and clarifies, conceptualizes and theorizes the concepts of radicalization and counter-radicalization. An in-depth examination of the efforts and contributions of FBOs in counter-radicalization forms the fourth part of the study. The fifth part evaluates the challenges facing these FBOs in addressing and combating radicalization within the Boko Haram context. The sixth part of the article presents the conclusion and policy implications of the study.

\section{Methodology}

This study is qualitative in that it critically examines primary and secondary documents, and uses interviews carried out with various key experts as key informant interviews and stakeholder interviews and focus group discussions with syndicate groups to assess the role played by FBOs and the challenges facing FBOs in counter-radicalization within the context of Boko Haram insurgency. These key informants and selected groups for the oral interviews were composed of religious leaders across the two dominant religions in Nigeria 
(Christianity and Islam), leaders of groups, denominations, and sects across the religious divides across northern Nigeria specifically, areas affected by the radicalization patterns and continuous activities of Boko Haram. These groups comprised leaders of the Christian Association of Nigeria (CAN) and the Jama'atu Nasrul Islam (JNI); leadership and clerics of denominations and sects such as the Church of Christ in Nations (COCIN), The Evangelical Church Winning All (ECWA), Ekklesiyar Yan'uwa a Nigeria (EYN), and the Tijaniyya brotherhood; academics and experts on the issues related to radicalization, terrorism, and violent extremism whose long-standing contributions and scholarship regarding the topic under investigation are clear. The views and opinions of the community and traditional leaders in areas affected by activities of Boko Haram who believe in the important role of religion in addressing the challenges of radicalization and counter-radicalization in northeast Nigeria, Lake Chad, and Sahel regions formed part of the KII's and stakeholder interviews with the authors. Respondents that were also drawn upon during the FGD sessions included leaders of associations like the Fellowship of Christian Students (FCS) and the Muslim Students Society, Church groups such as Youth Fellowship and Women wing, and members of civil society organizations who have also carried out several engagements on counter-radicalization in areas affected by Boko Haram.

The choice of these respondents was informed by their representing a target group with in-depth knowledge and expertise regarding the various radicalization processes of Boko Haram, and how this group and its activity affect the peace and stability of the northeast and Lake Chad regions. The opinions, views, and teachings of these key respondents and stakeholders have the potency to shape the thought processes of individuals, and the groups they each represent contribute to their selection process for the interviews. This research approach was adopted by the study to enhance the reliability and validity and address certain intended and unintended biases and inter-subjectivity issues associated with social science research (Uprety 2009; Guion et al. 2011).

The respondents were asked questions such as: what are the roles of FBOs in counterradicalization, especially within the Boko Haram context? What are the challenges facing FBOs in their efforts to counter these radical messages and narratives pushed by Boko Haram? How can these challenges be addressed by relevant stakeholders? The views of these respondents were transcribed using narrative analysis for better clarity, and are reflected in the study. In line with the ethics associated with research and interviews, the study respects and maintains the anonymity of the respondents, while referring to their areas of specialty and the area of stakeholder engagement and the association they represent. These stakeholder engagements and interviews, and the initial drafts of the study, were carried out between July 2019 and May 2021.

\section{Conceptual Framework, Literature Review and Theoretical Analysis: Faith-Based Organizations, Radicalization, and Counter-Radicalization}

\subsection{Faith Based Organization}

Faith-based organizations, by definition, are organizations and individuals whose philosophies are driven by certain religious beliefs, faiths, and spiritual values in society (Bielefeld and Cleveland 2013). The definition offered by Ferris (2005) provides a more comprehensive understanding, and refers to FBOs as religious organizations that are local or international organizations that often carry out various socio-cultural, humanitarian, developmental, and peacebuilding activities in the society. From these two definitions, one can say that according to their characteristics, FBOs are united individual religious groups with a local or international outlook that rely on donations (funding) from members and other religious groups, and often carry out several conflict management, humanitarian, developmental, and peacebuilding initiatives for the betterment of humanity and society at large (Thaut 2009; Eby et al. 2011; Lipsky 2011; Orji 2011; Ager et al. 2015; Petersen 2015; Tomalin 2015; Payne 2020).

As organizations established not for profit-making but inspired by religious beliefs to contribute meaningfully to the growth and development of humanity and society are classified as congregations and non-congregations, national and international networks 
in line with their social service wings, such as national religious bodies, charities, youth wings, etc., exist as free-standing religious organizations incorporated independently and separately with the other two types, despite their religious standings, such as the Catholic Church, Lutheran Church and Anglican Church, amongst others (Bopp and Fallon 2013). Within the public policy cycle, these organizations operate in line with the principle of inclusivity, which incorporates the two major Abrahamic religions (Christianity and Islam). They also help in easing the concerns raised by many regarding the role of religion and the state, whereby some were of the view there should be a clear separation between religion and the state because the two cannot coexist together (Graddy 2006; Clerkin and Grønbjerg 2007; Mallya 2010; Davis et al. 2011; Olarinmoye 2012). However, FBOs further demystify the narrative that religious organizations have an important role to play in the state and governance (Haynes 2014).

To avoid unnecessary ambiguity regarding the usage of the concept, within the operational context of this article, the term faith-based is used to look at how the two major Abrahamic religions (Christianity and Islam), and the various national groups and networks under these two major religions, contribute in the deradicalization process to counter the threats and activities of violent non-state actors like Boko Haram.

\subsection{Radicalization, Types, and It's Nexus with Terrorism and Terror-Behavior}

According to the United Kingdom Prevent Duty Guidance (2019), radicalization refers to the process through which an individual or group of persons supports the extremist and ideological values that promote terrorism and the activities of terror groups in society. defined the term radicalization as "a phased and complex process in which an individual or a group embraces a radical ideology or belief, uses or condones violence, including acts of terrorism, to reach a specific political or ideological purposes" (see The European Commission on Migration and Home Affairs 2020). Another definition put forward by IGI Global (2020) sees the term as "a process whereby an individual or a group comes to adopt increasingly extreme political, social or religious ideals and aspirations that reject or undermine the status quo". Research by Hafez and Mullins (2015) refers to radicalization as "a social and psychological process through which an individual or group accepts and gradually extremist political or religious beliefs that challenges the status quo and such persons or group are willing to achieve these extreme religious and political views violently in the state".

Several studies have argued that radicalization can be attributed to factors such as extreme poverty and social exclusion, the negative instrumentalization of religion by rogue and radical clerics, peer pressure and influence from friends and comrades with links to these extremist groups, the crisis of identity, exposure to extremist literature, national and global influence by proscribed terrorist groups, and more recently, the negative influence associated with the internet and social media as avenues and pathways through which vulnerable and impressionistic individuals are lured towards radicalization (Neumann 2003; Mandel 2009; Sedgwick 2010; Borum 2011a; Thompson 2011; Horgan and Altier 2012; Koehler 2014; Huey 2015; Lyons-Padilla et al. 2015; Doosje et al. 2016; McCauley and Moskalenko 2008, 2017; Sikkens et al. 2017; Van Eerten et al. 2017; Smith 2018; Torregrosa and Panizo 2018; Maza et al. 2020).

Studies by scholars on radicalization are of the view that radicalization, whether at the individual or group level, depending on its context, can be classified first into right-wing, closely linked to individuals and groups with fascist, racist, and ultranationalist ideologies who consider their beliefs and values to be supreme over other groups, especially immigrants, minorities and state actors whose policies and programs do not favor them and deploy violent means to achieve their aim. The second typology of radicalization is associated with individuals and groups with left-wing ideologies that are hostile towards capitalism and its socio-political and structural arrangement, which is said to be characterized by alienation, inequality, and exclusion. The third category of radicalization focuses on the single-issue paradox, whereby individuals and groups are motivated and driven by 
one issue or problem and use violent means to promote and achieve their aim. The fourth category of radicalization is associated with politico-religious variants in which individuals and groups are exposed to negative, hostile, and violent interpretations of religious and political texts, views, and narratives by elites to achieve their aim (Pisoiu 2015; Demetriou 2016; Rink and Sharma 2018; Sivenbring 2019; Lösel et al. 2020; Van den Bos 2020).

Given the fact that many studies attributed and linked radicalization to terrorism and terror behavior, further conceptual clarifications regarding these two concepts will further offer a clearer perspective and understanding regarding radicalization (Neumann 2003; Wilner and Dubouloz 2010; Bartlett and Miller 2012; Koomen and Van Der Pligt 2015; Jongman 2017). Conceptually, terrorism is also considered a highly contested concept given that the term itself means different things to different people. However, despite its contested nature, attempts have been made by several scholars, research organizations, policy think tanks, and government agencies to explain what the term entails. Jongman (2017) defined terrorism as the "calculated use of violence to create a general climate of fear in a population to achieve a political objective". The definition of the term by INTERPOL (2021) revealed that terrorism can be seen as actions and behaviors that involve a wide range of complex threats, including organized criminal networks, radicalized individuals and groups, and the use of chemical, biological, radiological, nuclear and explosive weapons to exert violence on innocent and defenceless non-combatants in order to achieve certain political and religious objectives. The Federal Bureau of Investigation (FBI) view terrorism as a series of actions and behaviors in which violent non-state actors, foreign or domestic, commit violent actions on innocent populations, for ideological, political, religious, or racial objectives (see Federal Bureau of Investigation 2021).

Terror behavior, it seeks to explain the various processes and stages through which terror groups progress before carrying out attacks. As argued by Olson (2012), it is important to note that most terror groups, irrespective of their nature, character, and location, think globally and act locally. In other words, they are mostly inspired by other designated foreign terrorist organizations in shaping their actions and their thought processes. Further analysis has revealed that terror behavior involves actions and behaviors whereby certain religious and political elites make speeches calling for racial, religious, or politically motivated violence; disseminating audio, visual and pictorial messages that call for violence on ideological, political, religious, and racial lines; inciting and recruiting people to carry out violent acts for ideological, political, racial and religious purposes (Smith 2008; Smith and Damphousse 2009; Smith et al. 2015; Klein et al. 2017). A study by the Indiana Intelligence Fusion Center (2021) also identified the following as signs of terror behavior. These include surveillance, whereby most terror groups, before carrying out any attack, observe and study carefully their chosen target in order to understand its strengths, weaknesses, and what method should be deployed. The second aspect of terror behavior involves a series of inquiries undertaken by the terror group in order to have the necessary information on its intended target. The third aspect involves the pre-test stage, where the terror group will attempt an attack on the target so as to ascertain the level of response from the security forces. The fourth and fifth stages involve the organization's recruitment and fundraising strategy to ensure its survival, procure the supplies needed for its operations, and show the organization's ability to entice individuals into believing in their cause. The sixth and seventh stages involve the organization engaging in what are considered "dry-runs", where the organization engages in practice sessions before the deployment of assets into the target location for the attack to take place. These periods are said to be crucial for terror groups because they enable them to marshal out plans, work out flaws, and measure the mission's success and unanticipated problems (see Indiana Intelligence Fusion Center 2021).

\subsection{Counter-Radicalization}

Conceptualizing or defining the term counter-radicalization, on the one hand, is challenging and ambiguous, as revealed by various studies (Coolsaet 2016; Stephens et al. 2019). 
This is largely because several studies have conflated the term with "preventing violent extremism" (PVE), which reflects idealistic, behavioral, and political thought processes opposing deviant actions that threaten the core values and stability of societies. In other words, PVE as a concept is said to be mostly driven by state actors or stakeholders to achieve a particular objective of stopping individuals from accepting violent extremism (Bartlett and Miller 2012). On the other hand, counter-radicalization involves the multisectoral involvement of both states and non-state actors in combating the various push, pull, and personal factors leading to individuals and groups accepting and promoting dangerous ideological, religious, and extremist views (Neumann 2003; Ozer and Bertelsen 2018; Vergani et al. 2020). However, despite the contested nature and definitional ambiguities regarding the term, counter-radicalization can be defined as the various economic, sociological, psychological, and religious methods or approaches used by relevant actors and stakeholders to prevent individual and group exposure to radicalization, terrorism, and all their effects in the society. Another definition offered by the European Union Commission (2020) describes the term counter-radicalization as several measures and initiatives designed by states and non-state actors to prevent the various sociological, psychological, religious, and political means and patterns that lead to radicalization. These initiatives include preventive measures against online radicalization, such as reforming and strengthening the criminal justice system to ensure fair trials and justice for both victims and the radicalized terror suspects, as well as reintegrating and building community engagement and resilience against the push, pull, and personal factors leading to individual and group radicalization (see European Union Commission 2020). These definitions seek to unravel the various economic, socio-cultural, ideological, religious, and psychological concerted strategies and initiatives designed by relevant actors to counter and prevent the transition of an individual or group into the various processes of radicalization and terror behavior, and such activities in society (Venhaus 2010; Rascoff 2012; Greenberg 2016; Pettinger 2017; Baaken et al. 2020; Mazerolle et al. 2020).

\subsection{Radicalization and Counter-Radicalization: Theoretical Analysis}

As proposed by Vidino (2011), to understand the concept of counter-radicalization, it is important to first understand the various theoretical discourse(s) on radicalization. This is because understanding the processes and drivers towards radicalization will enable experts and researchers to have a clear understanding and perspective when theorizing the concept and ideas regarding a mutually beneficial approach and strategy that can be adopted in any action geared towards counter-radicalization.

As put forward by Borum (2011b), there is no monolithic theory that explains radicalization. However, most studies on radicalization are of the view that the push, pull, and personal factors leading to individual and group exposure to radicalization at attributable to social movement theory, as well as the social psychology and economic-deprivation theories (Hafez and Mullins 2015; Vergani et al. 2020; Cherney et al. 2021; Leap and Young 2021).

The social movement theory emphasizes the stance that individuals' and groups exposure to radicalization stems from them being members of organizations that are formal, informal, or semi-structured (Beck 2008). These groups most often focus on a particular social ill facing society, through which they create a false narrative and promise unsuspecting persons that they offer a better alternative to solving these social problems. By their features, social movements are considered to be anti-establishment, anti-status quo, and anti-elitist, seeing these foes as reasons why the problems exist in the first place (Prud'homme 2019). These social movements mostly use negative religious rhetoric and messages to mobilize, recruit and carry out their violent and extremist agenda, given the fact that these anti-establishment narratives resonate at some level of consciousness in the minds of the people (Pieri and Zenn 2018). These groups continue to use their platforms to push intensify the embers of violence and extremism to ensure their survival and sustainability (Pieri and Zenn 2018; Prud'homme 2019). To further justify the theory's 
claim and stance on radicalization, its proponents criticized other scholars and experts who claimed that the 9/11 terror attack in the United States of America served as a precursor to the various violent processes and actions that propelled individuals and groups towards radicalization and engagement in acts promoting terrorism in society (Silber et al. 2007; Borum 2011a, 2011b; Neumann and Kleinmann 2013; Pieri and Zenn 2016; McCauley and Moskalenko 2017; Coolsaet 2019; Dawson 2019). They have been criticized for being misinformed or under-informed regarding the operational and theoretical understanding of radicalization and acts of terrorism. The criticism relates to the fact that radicalization dates back to the works of experts who have studied the negative influence of social movements and how they contribute to exposing individuals and groups to radicalization and terror-related activities (McAdam 2000; Benford 2002; Della Porta 2006, 2018; Snow and Cross 2011; Demetriou 2016). Relating this theory to the radicalization process and pattern of Boko Haram, several extant studies have traced the origin, recruitment, funding and survival patterns of the group to various social movements such as the Maitatsine, the Yobe Taliban, the Saharaba Muslim Youth Organization, the Sara-Suka movements, etc., considered hostile to the establishment and the modern state system, accusing it of creating a Nigerian society polluted by western values that they see as totally inimical to Islam (Rogers 2012; Mohammed 2018; Nwammuo and Salawu 2018; Pieri and Zenn 2018). It was movements like these that later transformed into the present-day Boko Haram.

The social psychology theory traces its origins to the academic field of psychology. This theory focuses on how individuals' and groups' relationships, interactions, and engagements lead them towards embracing radical and extremists ideologies (Williams 2020). A study by Bélanger et al. (2019), using the " 3 N Model" of need, narrative and networks, outlines the avenue for one to embrace extremist and violent worldviews related to radicalization. These studies have also emphasized personal and behavioral traits such as trauma, peer pressure, the need for self-recognition and belonging to a group, identity crisis, and the negative influence of poor mentorship by radical or rogue individuals in society as factors preparing a basis for radicalization (Post 2007; Beck 2008; McCauley and Moskalenko 2008; Neumann 2008; Dawson 2019; Ellis et al. 2019; Orsini 2020). Consistently, radical groups continue to use these models to not only recruit and mobilize individuals into embracing their views, but they also exploit their needs and vulnerabilities, and continue to sustain such false narratives of violence, and religious, ideological and racial hate, to achieve their objective (Bélanger et al. 2020).

The economic deprivation theoretical lens on radicalization focusses on the societal, economic, and structural conditions of poverty, inequality, corruption, alienation, unemployment, economic deprivation, and socio-cultural and religious cleavages in the society as preconditions for radicalization and drivers towards radicalization and extremist views (McCauley and Moskalenko 2008; Zaidi 2010; Maskaliūnaitè 2015; Kruglanski et al. 2019; Vergani et al. 2020). This is because these violent extremist groups exploit these factors and problems to push their agenda in society (Koomen and Van Der Pligt 2015; Hansen et al. 2016; Varaine 2020). This theory views these structural challenges as factors contributing to individuals' and group's paths to radicalization.

Relating these theoretical patterns to Boko Haram's radicalization pattern, several studies have linked the group's radicalization pattern to the religious-political elite's negative instrumentalization and harmonization of the social movement platform, the economic deprivation challenge, and the exploiting of the needs, narratives, and networks of individuals and groups in the society to achieve their agenda.

With these informed perspectives, it is important to note that any act related to counterradicalization should be able to address the structural factors, personal and behavioral patterns, and negative influence of social movements and their relationships in order to adequately address the paradox associated with radicalization and counter-radicalization in society. This is because embracing and adopting these three important factors is not only effective, but is also holistic in its approach to the understanding of radicalization and counter-radicalization today. 


\section{What Are the Efforts of Faith-Based Organizations in Counter-Radicalization in Nigeria: The Boko Haram Challenge?}

Counter-radicalization is a vital strategy for combating the activities of extremists, as well as radical and terrorist groups (Braddock 2020). This is because most of these organizations use religion negatively to instrumentalize their radical ideology to recruit, fund, sustain and expand their activities today (See Braddock 2020). Violent religious extremism and radicalization have been regarded as the primary drivers of modern terrorism (Van den Bos 2018). That is why most contemporary studies advocate for a counter-radicalization approach that seeks to address the radical and ideological underpinnings that promote these extremists and radical views, as well as to ensure effective collaboration and synergy between the state agencies and relevant stakeholders, such as community leaders and faith-based organizations (Foret and Markoviti 2020). The aim is to counter the negative messages and propaganda used by these groups and to strengthen the organizational, institutional, and logistical capacities of these stakeholders to effectively counter the threats posed by these radical and extremist groups (Onapajo 2017; Ahmed et al. 2018; Obamamoye 2018; Tella 2018; Banini 2020). Therefore, it is in this light that this section of the article will assess the efforts of and role played by FBOs in countering the extremist ideology promoted by Boko Haram.

It has been established that religion plays an important role in shaping individual behavior and moral compass, and also in defining the various sectarian fault lines and crises that have engulfed the Nigerian state since its independence (Olojo 2013). This narrative is mostly attributed to the high level of reverence given by worshipers of the two dominant religions (Christianity and Islam) to the various spiritual leaders, whereby certain rogue clerics tend to use their platforms to convey hateful and extremist ideologies leading to radicalization and other forms of violent extremism in the country (Sampson 2012; Iyekekpolo 2016). The radical views espoused by some clerics often lead to tension, conflicts, and riots, as witnessed during the Maitatsine uprising led by Muhammed Marwa in the 1980s, and exemplified by examples such as the case of constant tension and conflict between the Nigerian government and the Ibrahim Elzakzaky-led Shiite Movement of Nigeria, and the Boko Haram crisis, which has transformed into a complex security threat to the stability of not only Nigeria but also the neighboring states of Cameroun, Chad, and the Niger Republic. These represent examples of the negative use of religion destabilizing societies and also radicalizing individuals into terrorism and other violent extremist ideologies (Adesoji 2011; Bagaji et al. 2012; Alao 2013; Aghedo 2014; Osaghae 2017).

Several studies have shown that religious groups and institutions are sectors of society that have been negatively affected by the presence, actions and activities of the Boko Haram terrorist organization in the northeastern part of Nigeria and the greater Lake Chad region (Maiangwa et al. 2012; Elden 2014; Onapajo and Usman 2015; Regens et al. 2016). This is first because many of the radical clerics often use and interpret religious texts negatively, easily misleading and deceiving vulnerable persons into accepting their extremist views and teachings as the ultimate path to salvation (Maza et al. 2020). Secondly, as has also been revealed and confirmed by the key informant and stakeholder interviews, the churches, mosques, Christian and Islamic clerics, and innocent members of various religious divides are the greatest victims and casualties of the mayhem caused by Boko Haram. This narrative follows reports from prominent civil society organizations such as Amnesty International, Human Rights Watch, and the Nigerian Watch, which indicate that in 2018 alone, over 2134 people were killed at their various places of worship in northeast Nigeria and the greater part of Lake Chad, where the activities of this terrorist group are more pronounced (Amnesty International 2020; Human Rights Watch 2020). A cleric of the Evangelical Church Winning All clearly indicated and detailed this in an interview with the authors:

Faith-based organizations have become a soft target of attacks by Boko Haram, this is because, I can tell you the number of churches, mosques, Christians, Muslims, pastors, and imams being kidnapped and maimed by this group is 
alarming. Despite the open attack on FBOs, we will continue to pray for these boys so they can see the light, repent, and turn a new leaf. We will not abandon them, neither will we abandon our faith. We see this as the supreme price we all have to pay in order to save humanity and Nigerians from the vitriol of radicalization and terrorism which has become another global pandemic. ${ }^{2}$

Furthermore, as part of the efforts across the various religious divides in countering the elements of the radicalization of youth and children into extremism and terrorism, a prominent Islamic scholar in Gombe maintained in a discussion with the authors the important role played by FBOs:

Just like in Sokoto State where radical elements like Kabiru Sokoto who used their platform to indoctrinate vulnerable children into extremism were chased by members of the Islamic community, we in Gombe have been able to checkmate the excesses of these radical elements in our community by always countering some of these negative messages. In collaboration with other civil society groups, we have also supported several initiatives tailored towards countering violent messages that lured individuals into supporting and participating in acts of terrorism. ${ }^{3}$

A respondent from Gombe also offered the view that counter-radicalization involves "wars of ideas and dangerous ideologies" in communities, and emphasized that "Islamic associations under the Jama'atu Nasrul Islam (JNI) and Muslim Student Society of Nigeria (MSSN) have consistently challenged the rhetoric and radical teachings associated with Boko Haram and their sympathizers at various places of worships". ${ }^{4}$ The leader of the Muslim Students Society of Nigeria (MSSN) also elaborated on the importance of FBOs in countering radicalization:

In our Madrasas and Islamiya, ${ }^{5}$ several messages and teachings were given to these little children on the need to embrace peace, coexist peacefully with other communities, and individuals of different faiths, and not to accept radical teachings that will lead them to embrace extremism as an ideology. In fact, through the efforts and collaborations between our Islamic clerics, community leaders, local vigilantes, and other Muslim groups, we do not allow extremist preachers and preaching in our society. The moment we identified these radical preachers, we asked them to leave and not contaminate our society with their poisonous teachings and ideologies. This further explains why, despite our state being part of the northeast, it has contained and controlled the incursion by Boko Haram. ${ }^{6}$

Several extant studies also revealed that other prominent religious clerics, such as Ustaz Yusuf Inuwa, the late Sheikh Abba Aji, Sheikh Dahiru Usman, and the Supreme Head of the Islamic Council of Nigeria-the Sultan of Sokoto, continue to counter and denounce the various hateful and extremist messages of Boko Haram, describing their actions as not only being barbaric, but as acts of evil that should not be condoned and allowed to continue (see Olojo 2013; Clubb and Tapley 2018; Nnam et al. 2018). Recent studies further revealed that leaders of faith-based organizations continue to collaborate and provide platforms, alongside civil society organizations, that counter the various radical messages used by Boko Haram, intended to perpetuate their ideology (Olojo 2020; Ossai 2021). Moreover, the FBOs continue to engage with other sectors in venturing into the acquisition of various skills such as tailoring, artisanship, apprenticeship, and other technical vocations in order to reduce youth restiveness, and also to prevent them from being targets of recruitment by Boko Haram.

Consequently, it is important to note that counter-radicalization involves countering the various ideological and doctrinal forces that support extremism and terrorism (Hardy 2019). That is why FBOs continue to be at the forefront in combating these negative ideologies pushed by Boko Haram in its recruitment and expansionist strategy. This position can be seen through the collaboration between FBOs and state governments in northeast Nigeria in introducing peace studies and establishing peace clubs as part of 
the education and extracurricular engagements at the primary and secondary schools (TRT World 2018). The introduction of these peace clubs and peace studies was aimed at addressing the negative influence of ideology and the misrepresentation of religion by Boko Haram (see TRT World 2018). This initiative has also served to enable the youth and children to understand the importance of diversity management, tolerance, peaceful coexistence, and consolidation in society. ${ }^{7}$ In one of the authors' interviews, a pastor from the Ekklesiyar Yan'uwa a Nigeria (EYN) maintained that FBOs continue to collaborate with various stakeholders in addressing the challenges of radicalization and terrorism. This can be seen in the various interfaith engagements between Christians and Muslims in promoting peace through the organization of peace concerts, sports, and other recreational activities that are not only aimed at promoting and strengthening peace, but also addressing the various negative aspects of mistrust being promoted by those who wish to fuel the embers of violence and terror in society (Peace Direct 2016). Furthermore, in an interview with a peace advocate and senior program officer of one civil organization in northern Nigeria, it was maintained that Christian and Muslim leaders continue to pass their messages on in various television programs and talk shows such as the Ina-Mafita (WayForward) and Farar-Tattabara (White-Dove), using various themes in order to counter the negative ideologies, teachings, and messages that promote the terrorism of Boko Haram, as well as disunity, mutual suspicion, and other systemic and structural factors that create the space for religious radicalization to thrive. ${ }^{8}$ Other studies have also revealed that these radio and talk shows have had a positive impact in shaping viewers' and listeners' values and beliefs about the dangers associated with radicalization and other forms of violent extremism that promote the presence and activities of Boko Haram in Nigeria and the greater Lake Chad region (Marrone et al. 2020). This is indeed a good example of religious leaders and FBOs agreeing to coordinate their efforts to counter these negative doctrinal elements and teachings in society.

To this end, it is important for the relevant stakeholders to understand that despite the precarious nature of the resilience, actions, and activities of Boko Haram, FBOs have played a very significant role in not only countering the radicalization and recruitment of the weak and vulnerable into Boko Haram, but also used their platforms to continuously preach peace, promote mutual trust, and ensure that the negative doctrinal elements used by certain rogue and radical clerics are contained in order to deter individuals and groups from being sympathetic towards Boko Haram in Nigeria and the Lake Chad region through winning the hearts and minds of all. ${ }^{9}$

\section{Challenges Facing FBOs in Countering Boko Haram Radicalization}

Despite the efforts made by various stakeholders to contain the radicalization of individuals and groups towards Boko Haram, this terror group continues to expand its territorial base and presence across northeast Nigeria and the Lake Chad region. Boko Haram's presence and activities continue to thrive despite the role played by FBOs in countering the negative ideologies and messages of this group. Therefore, the fundamental question is this: what are the challenges confronting FBOs in countering the radicalization of individuals and groups despite the continuous and sustained efforts made by these sectors to combat it?

An interview with a terrorism expert revealed that most extant studies situate the challenges of counter-radicalization and the persistent attacks of Boko Haram in the emphasis placed by state actors on the reductive and traditional approach of heavily employing the "use of force" and military might. This is because the state-centric response and approach cannot understand how to identify and proffer solutions on how to counter the push, pull, and personal factors responsible for individual and group exposure to radicalization. The approach is also said to have affected and downplayed the role of FBOs in countering the various negative doctrinal teachings of Boko Haram aimed at enticing individuals and groups into joining them..$^{10}$ Consequently, as the government continues to focus on this "state-centric approach", thereby negating other non-violence approaches, the roles and 
voices of FBOs cannot effectively address the problems associated with radicalization, not only in Nigeria but also in other regions facing similar challenges of violent extremism and terrorism. ${ }^{11}$ Several studies have suggested that the continued reliance on the "use of force" in countering the activities and expansion of Boko Haram causes the mutual suspicion of the people, and the inability of state actors to address cases and incidences, whereby some members of the task force mandated to counter the activities of this violent group are guilty of committing various acts of human rights abuses on innocent and defenseless people (Onapajo 2017; Olojo 2019; Hansen 2020; Wodu 2020). This failure has led to increasing suspicion and the genuine intentions of the military and the various counter-radicalization initiatives designed to combat the radicalization process of Boko Haram (Ike et al. 2021).

Another challenge facing FBOs in combating the extremist and ideological teachings of Boko Haram relates to the fact that the Nigerian state and other relevant actors have not been able to tackle socio-economic, political, and structural factors such as alienation, poverty, unemployment, socio-economic exclusion, and lack of access to the basic necessities of life as contributors to Boko Haram's violence and expansion (Mustapha 2014). This position was further confirmed by a respondent who was of the view that the deliberate policies and actions of the state leading to the high rates of poverty, unemployment, bad governance, and lack of access to essential services in Nigeria continue to affect the efforts of FBOs in countering these negative teachings and messages preached by Boko Haram. ${ }^{12}$ It should be emphasized that many individuals that join this terror group identify poverty and the enticing financial promises made by Boko Haram as reasons for joining these groups; an open secret that is also put forward by various studies (Onuoha 2014; Allan et al. 2015; Ewi and Salifu 2017; Farzanegan and Witthuhn 2017; Mythen 2020). An interviewed youth leader with the Church of Christ in Nations (COCIN) revealed this concern powerfully to the authors:

How do you expect an individual to renounce violence and terrorism when he/she believes that through that means, they can effectively improve their economic and material condition? You cannot preach to someone to renounce radicalization when these systemic and structural imbalances continue to exist. Therefore, to combat this problem, the Nigerian government and other relevant actors need to also ensure that these structural factors are adequately addressed. ${ }^{13}$

Another critical challenge confronting FBOs in their deradicalization efforts, as indicated by various respondents as well, is centered on the paradox of the "non-inclusion" of this critical sector by state actors whenever any policy is being initiated that involves deradicalization, demobilization, and disengagement. ${ }^{14}$ This is because the starting point for radicalization is the indoctrination and misrepresentation of religion by rogue clerics aiming to achieve a violent negative agenda in society. Therefore, any effort made towards disengagement and deradicalization should involve FBOs in driving the process because of the important roles they play in society as well as their ability to appeal to the hearts, minds, and conscience of individuals and groups in the society. An interviewed clergy member and an academic emphasized this challenge by arguing that many state actors and policymakers did not come to the realization that the Boko Haram crisis is, first of all, a religious problem before attributing other elements, such as socio-economic, political, and cultural colorations, to it. He maintained that:

The inability or negligence by these policy actors not to see it first as a religious problem, and addressing it requires the inclusion and input by various FBOs. The place and role of FBOs will continue to be undermined in the various disengagement and deradicalization processes. Therefore, it is incumbent on these relevant key stakeholders to involve this critical sector if they wish to achieve the objective of tackling the Boko Haram challenge in Nigeria and other countries affected by the actions of this group across Lake Chad. ${ }^{15}$

This position was further supported in reports made by relevant agencies that challenged the ongoing "Operation Safe Corridor"16 policy initiative for not involving and 
allowing clerics to drive the process. Scholars highlight the non-inclusion of FBOs in the policy initiative among other challenges, such as the secrecy surrounding the policy, negligence, and poor treatment applied to the participants of the program, communities suspicion of the participants, lack of acceptance of the program by Nigerians, lack of follow-up on the welfare of the participants, and absence of post-radicalization initiatives (see Brechenmacher 2018; see Felbab-Brown 2018; see International Crisis Group 2021).

Fear of reprisal is also identified as one of the critical challenges facing FBOs in their quest and efforts to deradicalize individuals and groups from terrorism and other forms of violent extremism in Nigeria. This is because many religious leaders who spoke openly against Boko Haram's ideology in their various places of worship and platforms were attacked, kidnapped, or killed (Olojo 2017; Lar 2019; Egwu 2021). This position was further confirmed to the authors during an interview when one respondent put forward the view that the various assassination attempts on Sheikh Dahiru Bauchi were because of his vocal stance and the several counter messages he made against Boko Haram's ideology in northern Nigeria. ${ }^{17}$ Against this backdrop, most clerics and FBOs have become increasingly cautious in taking radical steps against the weaponization and misrepresentation of religion by these extremist groups.

During a syndicate session with participants in the focus group discussions, the participants expressed the fear that to effectively counter the ideological forces of Boko Haram and other violent extremist groups, there should be total unison and harmonization between faith-based groups, civil society organizations, community leaders, state actors and other key stakeholders in order to achieve the desired outcome/result. The participants also emphasized that the absence of this impedes the effectiveness of any deradicalization effort to combat the expansion of Boko Haram and its activities. Another respondent also argued that

so long as there are forces of mistrust between Christians, Muslims, and religious groups regarding countering the negative ideologies of Boko Haram, the group will continue to wax stronger, expand its territorial base and attract more sympathizers. This is because religious leaders and other key actors are always at loggerheads and treating each other with negative biases and mistrust. ${ }^{18}$

Therefore, it is important to note that FBOs are critical in the deradicalization process in terms of limiting and countering the negative propagation of Boko Haram, but they are confronted with the above challenges on a daily basis. This invariably inhibits their effectiveness in achieving that goal as Boko Haram continues to advance and expand its territorial frontiers beyond the northeastern part of Nigeria to other regions as well.

\section{Conclusions}

For over a decade now, the Nigerian government and its security agencies have been grappling with the expansion and activities of the Boko Haram terrorist group, which saw the northeast region and the greater Lake Chad region become the epicenter of the terror and violence committed by this group. Several counterterrorism measures have been taken by the state to counter this group. However, this approach has not been able to de-escalate the activities of this group. Many studies have demonstrated the need to incorporate not only soft-power but also smart-power to complement pre-existing CTR to effectively address this challenge. These studies have also emphasized the important role played by FBOs in tackling the negative ideologies and messages used by this group to attract and recruit vulnerable and impressionistic individuals and groups into embracing their negative ideologies.

This article examined the critical contribution made by FBOs in countering the negative instrumentalization and misrepresentation of religion by this terror group to achieve its agenda in the northeast region and the greater Lake Chad region. However, despite the important role of these FBOs in countering the negative application of religion to lure unsuspecting persons into Boko Haram, the findings of this study reveal further that the lack of unison by these actors, non-inclusion, the non-representation of this sector in the 
various CTR initiatives by the state, the poverty question, fear of reprisal and the inability to address structural challenges that gave rise to this group are challenges facing FBOs in their deradicalization efforts to counter the activities of this terror group.

To address these challenges, this article proposes the following recommendations for effective disengagement against the negative ideology and messages of Boko Haram:

- A bottom-up counter-radicalization approach should be developed that involves and incorporates every stakeholder to make the approach less state-centric and reductionist;

- Continued support and protection should be guaranteed for FBOs and other vocal clerics who use their platforms to constantly speak against the negative representation of religion by certain rogue elements in society to support Boko Haram, terrorism, and other forms of violent extremism;

- The state and its agencies should address structural challenges such as poverty, unemployment, non-inclusion, and other forms of social injustice in society to deter vulnerable and idle individuals and groups from embracing negative ideologies;

- There should be a deliberate effort made by relevant stakeholders to also address non-violent forms of radicalization such as hate speech, rhetoric, and distortions of religious texts by rogue clerics, as these are the precursors to the violent forms of radicalization in society;

- There should be proper synergy and cooperation within FBOs by allaying any form of mistrust and disunity when combating negative messages and ideologies of Boko Haram and other violent extremist groups;

- $\quad$ FBOs and other key stakeholders should not only identify the push, pull, and personal factors contributing to the radicalization of youth and the vulnerable in the northeast and other regions affected by Boko Haram, but they should also make a concerted effort to ensure that these three (Ps) are addressed and prevented in society;

- There should be strategic and multi-sectoral engagement between state actors, FBOs, CSOs, NGOs, the community, and religious leaders to address and counter the ideological, membership, and funding activities of Boko Haram and their sympathizers for effective counter-radicalization and disengagement efforts;

- Punitive measures should be taken by relevant stakeholders to check the activities of extremist clerics in the society through the strengthening and enhancing of the operational capacity of the criminal justice system in discharging its duties and mandate;

- As an avenue for further studies, future researchers are also encouraged to examine how clerics use their platforms and other social media tools to counter the various messages and ideologies preached by terror and other violent extremist groups. This is because several studies have also assessed the use of social media and its tools as a recruitment hub for such groups;

- Researchers interested in studying radicalization and counter-radicalization are also encouraged to broaden their scope of engagement, and interviews should not only focus on key stakeholders or informants but should also involve other members of various FBOs at the middle and lower levels to understand their feelings and sentiments towards radicalization and counter-radicalization, as well as its implications for the stability and progress of societies. Involving some of these middle- and lower-level members of these organizations will also contribute to shedding more light on issues around radicalization and counter-radicalization.

Author Contributions: Conceptualization, B.I., S.A., and K.D.M.; methodology, B.I., S.A., and K.D.M.; formal analysis, B.I., S.A., and K.D.M.; investigation, B.I., S.A., and K.D.M.; writing-original draft preparation, B.I., and K.D.M.; writing-review and editing, S.A., and K.D.M.; supervision, S.A. All authors have read and agreed to the published version of the manuscript.

Funding: This research received no external funding.

Institutional Review Board Statement: Not applicable.

Informed Consent Statement: Not applicable. 


\section{Data Availability Statement: Not applicable.}

Conflicts of Interest: The authors declare there is no potential conflict of interest.

\section{Notes}

1 As a terror group, Boko Haram believes in the abolition of Western education, the current state structure in Nigeria, the implementation of the Sharia Legal system, and a caliphate system of governance in Nigeria. Since 2009, the group has carried out a series of violent and deadly attacks across various sectors in the northeastern part of Nigeria, as well as the Lake Chad and Sahel regions.

2 Author interview with a Senior Pastor with the Evangelical Church Winning All (ECWA), Jos, 13 January 2021.

3 Interview with an Islamic Cleric in Gombe, 20 January 2021.

4 Author phone interview with a member and leader of the Muslim Students Society of Nigeria (MSSN), Gombe State Chapter, 19 March 2021.

5 Madrasas and Islamiya refer to Islamic schools where children at an early age are taught teachings according to Islamic injunctions as enshrined in the Quran and Hadith.

6 Author phone interview with a member and leader of the Muslim Students Society of Nigeria (MSSN), Gombe State Chapter, 19 March 2021.

7 Interview with a Peace Club Teacher in Maiduguri, 12 February 2021.

8 Interview with a senior program officer at Equal Access International (EIA), a civil society organization that helps communities and societies achieve the needed positive and sustainable transformative change, Kaduna-Nigeria, 3 March 2021.

9 Oral discussion with selected KIIs during the author's syndicate discussion on the important role played by FBOs in countering the negative messages of Boko Haram in the Northeast and Lake Chad, 19 March 2021. Author's interview with a terrorism expert at the University of Nigeria, Nsukka, 3 February 2021.

Interview, 3 February 2021.

12 Interview with a respondent and lecturer in the Department of History \& International Studies, University of Maiduguri, Nigeria, 9 February 2021.

13 Authors discussion/interview with a Youth Leader at COCIN RCC Borno, Nigeria, 12 February 2021.

14 Interview with a Resident Pastor at ECWA Central Church, Gombe, 12 March 2021.

15 Oral interview with a cleric and academic with the Department of Religious Studies, Kaduna State University (KASU), 13 March 2021.

16 A policy initiative designed in 2016 by the Nigerian government in order to demobilize, deradicalize, rehabilitate, and reintegrate repentant Boko Haram combatants into society after undergoing a series of psycho-spiritual and social therapy sessions.

17 Interview with a prominent member of the Tijaniyya brotherhood with Sufist ideology, Bauchi-Nigeria, 19 February 2021.

18 Author interview with a clergyman and Professor of Religion and Cultural Studies, University of Nigeria, Nsukka, Nigeria, 16 April 2021.

\section{References}

Adenrele, Adetoro Rasheed. 2012. Boko Haram insurgency in Nigeria as a symptom of poverty and political alienation. IOSR Journal of Humanities and Social Science 3: 21-26. [CrossRef]

Adesoji, Abimbola O. 2011. Between Maitatsine and Boko Haram: Islamic fundamentalism and the response of the Nigerian state. Africa Today 57: 99-119. [CrossRef]

Agbiboa, Daniel Egiegba. 2013. Why Boko Haram exists: The relative deprivation perspective. African Conflict and Peacebuilding Review 3: 144-57. [CrossRef]

Agbiboa, Daniel Egiegba. 2020. The precariousness of protection: Civilian defense groups countering Boko Haram in Northeastern Nigeria. African Studies Review 64: 1-25. [CrossRef]

Ager, Joey, Elena Fiddian-Qasmiyeh, and Alastair Ager. 2015. Local faith communities and the promotion of resilience in contexts of humanitarian crisis. Journal of Refugee Studies 28: 202-21.

Aghedo, Iro. 2014. Old wine in a new bottle: Ideological and operational linkages between Maitatsine and Boko Haram revolts in Nigeria. African Security 7: 229-50. [CrossRef]

Ahmed, Kawser, Patrick Belanger, and Susan Szmania. 2018. Community-Focused Counter-Radicalization and Counter-Terrorism Projects: Experiences and Lessons Learned. Lanham: Rowman \& Littlefield.

Akinola, Olabanji. 2015. Boko Haram insurgency in Nigeria: Between Islamic fundamentalism, politics, and poverty. African Security 8: 1-29. [CrossRef]

Alao, Abiodun. 2013. Islamic radicalisation and violent extremism in Nigeria. Conflict, Security E Development 13: $127-47$.

Allan, Harriet, Andrew Glazzard, Sasha Tumu Jesperson, and Emily Sneha Reddy Winterbotham. 2015. Drivers of Violent Extremism: Hypotheses and Literature Review. London: RUSI. 
Amnesty International. 2020. 'Nigeria 202'. Report 2020/2021. Available online: https:/ /www.amnesty.org/en/wp-content/uploads / 2021/06/English.pdf (accessed on 15 June 2021).

Arshad-Ayaz, Adeela, and M. Ayaz Naseem. 2017. Creating "invited" spaces for counter-radicalization and counter-extremism education. Diaspora, Indigenous, and Minority Education 11: 6-16. [CrossRef]

Ayegba, Usman Solomon. 2015. Unemployment and poverty as sources and consequence of insecurity in Nigeria: The Boko Haram insurgency revisited. African Journal of Political Science and International Relations 9: 90-99.

Azumah, John. 2015. Boko Haram in retrospect. Islam and Christian-Muslim Relations 26: 33-52. [CrossRef]

Baaken, Till, Judy Korn, Maximilian Ruf, and Dennis Walkenhorst. 2020. Dissecting deradicalization: Challenges for theory and practice in Germany. International Journal of Conflict and Violence (IJCV) 14: 1-18.

Bagaji, Ali S. Yusufu, Moses Shaibu Etila, and Elijah E. Ogbadu. 2012. Boko Haram and the recurring bomb attacks in Nigeria: Attempt to impose religious ideology through terrorism? Cross-Cultural Communication 8: 33-41.

Banini, Daniel Kofi. 2020. Security sector corruption and military effectiveness: The influence of corruption on countermeasures against Boko Haram in Nigeria. Small Wars E Insurgencies 31: 131-58.

Bartlett, Jamie, and Carl Miller. 2012. The edge of violence: Towards telling the difference between violent and non-violent radicalization. Terrorism and Political Violence 24: 1-21. [CrossRef]

Beck, Collin J. 2008. The contribution of social movement theory to understanding terrorism. Sociology Compass 2: 1565-81. [CrossRef]

Bélanger, Jocelyn J., Blaine G. Robbins, Hayat Muhammad, Manuel Moyano, Claudia F. Nisa, Birga M. Schumpe, and Michelle Blaya-Burgo. 2020. Supporting political violence: The role of ideological passion and social network. Group Processes E Intergroup Relations 23: 1187-203.

Bélanger, Jocelyn J., Manuel Moyano, Hayat Muhammad, Lindsy Richardson, Marc-André K. Lafrenière, Patrick McCaffery, Karyne Framand, and Noëmie Nociti. 2019. Radicalization leading to violence: A test of the 3N model. Frontiers in Psychiatry 10: 42. [CrossRef]

Benford, Robert D. 2002. Controlling narratives and narratives as control within social movements. In Stories of Change: Narrative and Social Movements. Edited by Joseph E. Davis. New York: State University of New York Press, pp. 53-75.

Bielefeld, Wolfgang, and William Suhs Cleveland. 2013. Defining faith-based organizations and understanding them through research. Nonprofit and Voluntary Sector Quarterly 42: 442-67. [CrossRef]

Bopp, Melissa, and Elizabeth A. Fallon. 2013. Health and wellness programming in faith-based organizations: A description of a nationwide sample. Health Promotion Practice 14: 122-31. [CrossRef]

Borum, Randy. 2011a. Radicalization into violent extremism II: A review of conceptual models and empirical research. Journal of Strategic Security 4: 37-62. [CrossRef]

Borum, Randy. 2011b. Rethinking radicalization. Journal of Strategic Security 4: 1-6.

Braddock, Kurt. 2020. Weaponized Words: The Strategic Role of Persuasion in Violent Radicalization and Counter-Radicalization. Cambridge: Cambridge University Press.

Brechenmacher, Saskia. 2018. Achieving Peace in Northeast Nigeria: The Reintegration Challenge. Carnegie Endowment for International Peace, September 5. Available online: https: / / carnegieendowment.org/2018/09/05/achieving-peace-in-northeast-nigeria-reinte gration-challenge-pub-77177 (accessed on 10 April 2021).

Campbell, John. 2014. US Policy to Counter Nigeria's Boko Haram (No. 70). Special Report No. 70. November. New York: Council on Foreign Relations.

Casimir, Ani, C. T. Nwaoga, and Rev. Fr. Chrysanthus Ogbozor. 2014. Religion, violence, poverty and underdevelopment in West Africa: Issues and challenges of Boko Haram phenomenon in Nigeria. Open Journal of Philosophy 4: 59. [CrossRef]

Cherney, Adrian, Idhamsyah E. Putra, Vici Sofianna Putera, Fajar Erikha, and Muhammad Faisal Magrie. 2021. The push and pull of radicalization and extremist disengagement: The application of criminological theory to Indonesian and Australian cases of radicalization. Journal of Criminology 54: 407-24. [CrossRef]

Clerkin, Richard M., and Kirsten A. Grønbjerg. 2007. The capacities and challenges of faith-based human service organizations. Public Administration Review 67: 115-26. [CrossRef]

Clubb, Gordon, and Marina Tapley. 2018. Conceptualising de-radicalisation and former combatant re-integration in Nigeria. Third World Quarterly 39: 2053-68. [CrossRef]

Coolsaet, Rik. 2016. 'All Radicalisation Is Local': The Genesis and Drawbacks of an Elusive Concept (Vol. 84). Brussels: Egmont-Royal Institute for International Relations.

Coolsaet, Rik. 2019. Radicalization: The origins and limits of a contested concept. In Radicalisation in Belgium and the Netherlands: Critical Perspectives on Violence and Security. London: IB Tauris, pp. 29-51.

Cozzens, Jeffrey B. 2006. Identifying Entry Points of Action in Counter Radicalisation: Countering Salafi-Jihadi Ideology through Development Initiatives. Strategic Openings (No. 2006: 6). DIIS Working Paper. Copenhagen: Danish Institute for International Studies.

Davis, Comfort, Ayodele Jegede, Robert Leurs, Adegbenga Sunmola, and Ukoho Ukiwo. 2011. Comparing Religious and Secular NGOs in Nigeria: Are Faith-Based Organizations Distinctive? Working Paper. Birmingham: University of Birmingham.

Dawson, Lorne. 2019. Clarifying the explanatory context for developing theories of radicalization: Five basic considerations. Journal for Deradicalization 18: 146-84.

Della Porta, Donatella. 2006. Social Movements, Political Violence, and the State: A Comparative Analysis of Italy and Germany. Cambridge: Cambridge University Press. 
Della Porta, Donatella. 2018. Radicalization: A relational perspective. Annual Review of Political Science 21: 461-74. [CrossRef]

Demetriou, Chares. 2016. Dynamics of Political Violence: A Process-Oriented Perspective on Radicalization and the Escalation of Political Conflict. London: Routledge.

Doosje, Bertjan, Fathali M. Moghaddam, Arie W. Kruglanski, Arjan De Wolf, Liesbeth Mann, and Allard R. Feddes. 2016. Terrorism, radicalization and de-radicalization. Current Opinion in Psychology 11: 79-84. [CrossRef]

Eby, Jessica, Erika Iverson, Jenifer Smyers, and Erol Kekic. 2011. The faith community's role in refugee resettlement in the United States. Journal of Refugee Studies 24: 586-605. [CrossRef]

Egwu, Patrick. 2021. Christian clergy are being kidnapped and killed in Nigeria. The Christian Century, March 29.

Elden, Stuart. 2014. The geopolitics of Boko Haram and Nigeria's 'war on terror'. The Geographical Journal 180: 414-25. [CrossRef]

Ellis, B. Heidi, Georgios Sideridis, Alisa B. Miller, Saida M. Abdi, and Jeffrey P. Winer. 2019. Trauma, trust in government, and social connection: How social context shapes attitudes related to the use of ideologically or politically motivated violence. Studies in Conflict $\mathcal{E}$ Terrorism 44: 1-18. [CrossRef]

El-Said, Hamed, and Jane Harrigan. 2018. Deradicalising Violent Extremists: Counter-Radicalisation and Deradicalisation Programmes and Their Impact in Muslim Majority States. London: Routledge.

European Commission on Migration and Home Affairs. 2020. Prevention of Radicalization. Available online: https://ec.europa.eu/h ome-affairs/what-we-do/policies / counter-terrorism-and-radicalisation/prevention-radicalisation_en (accessed on 16 October 2021).

European Union Commission. 2020. Communication from the Commission to the European Parliament, the European Council, the Council, the European Economic and Social Committee and the Committee of the Regions: A CounterTerrorism Agenda for the EU: Anticipate, Prevent, Protect, Respond'. COM (2020) 795 Final. Available online: https: / / ec.europa.eu/home-affairs /system/files/2020-12/09122020_communication_commission_european_parliament_the_cou ncil_eu_agenda_counter_terrorism_po-2020-9031_com-2020_795_en.pdf (accessed on 16 October 2021).

Evans, Olaniyi, and Ikechukwu Kelikume. 2019. The impact of poverty, unemployment, inequality, corruption and poor governance on Niger Delta militancy, Boko Haram terrorism and Fulani herdsmen attacks in Nigeria. International Journal of Management, Economics and Social Sciences (IJMESS) 8: 58-80. [CrossRef]

Ewi, Martin A., and Uyo Salifu. 2017. Money Talks_A Key Reason Youths Join Boko Haram. ISS Policy Brief Number 98 . Available online: https:/ / issafrica.s3.amazonaws.com/site/uploads/policybrief98.pdf (accessed on 17 March 2021).

Falode, Adewunmi James. 2016. Countering the Boko Haram group in Nigeria: The relevance of hybrid doctrine. Small Wars Journal. Available online: https:/ / ssrn.com/abstract=2893262 (accessed on 16 October 2021).

Farzanegan, Mohammad Reza, and Stefan Witthuhn. 2017. Corruption and political stability: Does the youth bulge matter? European Journal of Political Economy 49: 47-70. [CrossRef]

Federal Bureau of Investigation. 2021. What We Investigate: Terrorism. Available online: https://www.fbi.gov/investigate/terrorism (accessed on 17 October 2021).

Felbab-Brown, Vanda. 2018. In Nigeria, we don't want them back. Brookings Report, May. Available online: https://www.brookings.ed $\mathrm{u} /$ research/in-nigeria-we-dont-want-them-back/ (accessed on 9 April 2021).

Ferris, Elizabeth. 2005. Faith-based and secular humanitarian organizations. International review of the Red Cross 87: 311-25. [CrossRef]

Foret, François, and Margarita Markoviti. 2020. New challenge, old solutions? Religion and counter-radicalisation in the European Parliament and the radicalisation awareness network. European Politics and Society 21: 434-51. [CrossRef]

Graddy, Elizabeth A. 2006. How do they fit? Assessing the role of faith-based organizations in social service provision. Journal of Religion E Spirituality in Social Work: Social Thought 25: 129-50.

Greenberg, Karen J. 2016. Counter-radicalization via the internet. The ANNALS of the American Academy of Political and Social Science 668: 165-79. [CrossRef]

Guion, Lisa A., David C. Diehl, and Debra McDonald. 2011. Conducting an In-Depth Interview. EDIS. No. 8. Available online: https://journals.flvc.org/edis/article/download/127025/126671 (accessed on 17 October 2021).

Hafez, Mohammed, and Creighton Mullins. 2015. The radicalization puzzle: A theoretical synthesis of empirical approaches to homegrown extremism. Studies in Conflict $\mathcal{E}$ Terrorism 38: 958-75.

Hansen, William. 2020. The ugly face of the state: Nigerian security forces, human rights and the search for Boko Haram. Canadian Journal of African Studies/Revue Canadienne des Études Africaines 54: 299-317. [CrossRef]

Hansen, William W., Kingsley Jima, Nurudeen Abbas, and Basil Abia. 2016. Poverty and "Economic Deprivation Theory" Street Children, Qur'anic Schools/almajirai and the Dispossessed as a Source of Recruitment for Boko Haram and other Religious, Political and Criminal Groups in Northern Nigeria. Perspectives on Terrorism 10: 83-95.

Hardy, Robin A. 2019. Countering violent extremism in Sub-Saharan Africa: What policy makers need to know. World Affairs 182: 256-72. [CrossRef]

Haynes, Jeffrey. 2014. Faith-based organizations at the United Nations. In Faith-Based Organizations at the United Nation. New York: Palgrave Macmillan, pp. 1-28.

Horgan, John, and Mary Beth Altier. 2012. The future of terrorist de-radicalization programs. Georgetown Journal of International Affairs 13: 83-90.

Huey, Laura. 2015. This is Not Your Mother's Terrorism: Social Media, Online Radicalization and the Practice of Political Jamming. Journal of Terrorism Research 6: 1-16. [CrossRef] 
Human Rights Watch. 2020. 'Nigeria: Events of 2019'. Human Rights Report. Available online: https://www.hrw.org/world-report/2 020/country-chapters/nigeria\# (accessed on 15 June 2021).

IGI Global. 2020. ‘What Is Radicalization'? Available online: https:/ / www.igi-global.com/dictionary/the-evolution-of-terrorism-thr eats / 64003 (accessed on 15 October 2021).

Ike, Tarela Juliet, Danny Singh, Dung Ezekiel Jidong, Sean Murphy, and Evangelyn Ebi Ayobi. 2021. Rethinking reintegration in Nigeria: Community perceptions of former Boko Haram combatants. Third World Quarterly 42: 661-78. [CrossRef]

Indiana Intelligence Fusion Center. 2021. 8 Signs of Terrorism. Available online: https://www.in.gov/iifc/8-signs-of-terrorism/ (accessed on 13 October 2021).

International Crisis Group. 2021. “An Exit from Boko Haram? Assessing Nigeria's Operation Safe Corridor" International Crisis Group. Policy Briefing. No. 170/Africa. Available online: https://www.crisisgroup.org/africa/west-africa/nigeria/b170-exit-b oko-haram-assessing-nigerias-operation-safe-corridor (accessed on 14 April 2021).

INTERPOL. 2021. Terrorism: "Methods, Motives and Money". Available online: https://www.interpol.int/en/Crimes/Terrorism (accessed on 17 October 2021).

Iyekekpolo, Wisdom Oghosa. 2016. Boko Haram: Understanding the context. Third World Quarterly 37: 2211-28. [CrossRef]

Iyekekpolo, Wisdom Oghosa. 2020. Political elites and the rise of the Boko Haram insurgency in Nigeria. Terrorism and Political Violence 32: 749-67. [CrossRef]

Jongman, Albert J. 2017. Political Terrorism: A New Guide to Actors, Authors, Concepts, Data Bases, Theories, and Literature. London: Routledge.

Khalil, Lydia. 2012. US Counter-Radicalisation Strategy: The Ideological Challenge. Canberra: Australian Strategic Policy Institute.

Klein, Brent R., Jeff Gruenewald, and Brent L. Smith. 2017. Opportunity, group structure, temporal patterns, and successful outcomes of far-right terrorism incidents in the United States. Crime \& Delinquency 63: 1224-49.

Koehler, Daniel. 2014. The radical online: Individual radicalization processes and the role of the Internet. Journal for Deradicalization 1: 116-34.

Koomen, Willem, and Joop Van Der Pligt. 2015. The Psychology of Radicalization and Terrorism. London: Routledge.

Kruglanski, Arie W., Jocelyn J. Bélanger, and Rohan Gunaratna. 2019. The Three Pillars of Radicalization: Needs, Narratives, and Networks. New York: Oxford University Press.

Kursuncu, Ugur, Manas Gaur, Carlos Castillo, Amanuel Alambo, Krishnaprasad Thirunarayan, Valerie Shalin, Dilshod Achilov, I. Budak Arpinar, and Amit Sheth. 2019. Modeling islamist extremist communications on social media using contextual dimensions: Religion, ideology, and hate. Proceedings of the ACM on Human-Computer Interaction 3: 1-22. [CrossRef]

Lar, Jimam Timchang. 2019. Violence and Insecurity in Northwest Nigeria: Exploring the Role and Resilience of Local Actors. African Conflict and Peacebuilding Review 9: 123-42. [CrossRef]

Leap, Bethany, and Joseph Young. 2021. Radicalization and Deradicalization. In Oxford Research Encyclopedia of International Studies. London: Oxford University Press.

Lipsky, Alyson B. 2011. Evaluating the strength of faith: Potential comparative advantages of faith-based organizations providing health services in sub-Saharan Africa. Public Administration and Development 31: 25-36. [CrossRef]

Lösel, Friedrich, Doris Bender, Irina Jugl, and Sonja King. 2020. Resilience against political and religious extremism, radicalization, and related violence: A systematic review of studies on protective factors. Understanding Recruitment to Organized Crime and Terrorism, 55-84. [CrossRef]

Lyons-Padilla, Sarah, Michele J. Gelfand, Hedieh Mirahmadi, Mehreen Farooq, and Marieke Van Egmond. 2015. Belonging nowhere: Marginalization \& radicalization risk among Muslim immigrants. Behavioral Science E Policy 1: 1-12.

Maiangwa, Benjamin, Ufo Okeke Uzodike, Ayo Whetho, and Hakeem Onapajo. 2012. "Baptism by Fire": Boko Haram and the reign of terror in Nigeria. Africa Today 59: 41-57. [CrossRef]

Mallya, Ernest T. 2010. Faith-based organizations, the state and politics in Tanzania. In Development and Politics from Below. London: Palgrave Macmillan, pp. 131-51.

Mandel, David R. 2009. Radicalization: What does it mean? Home-Grown Terrorism 60: 101-13.

Marrone, James V., Todd C. Helmus, Elizabeth Bodine-Baron, and Christopher Santucci. 2020. Countering Violent Extremism in Nigeria: Using a Text-Message Survey to Assess Radio Programs. Santa Monica: Rand Arroyo Center.

Martin, Thomas. 2020. The radical ambitions of counter-radicalization. The British Journal of Sociology 72: 270-85. [CrossRef]

Maskaliūnaitè, Asta. 2015. Exploring the theories of radicalization. International Studies: Interdisciplinary Political and Cultural Journal (IS) 17: 9-26. [CrossRef]

Maza, Kangdim Dingji, Umut Koldas, and Sait Aksit. 2020. Challenges of Countering Terrorist Recruitment in the Lake Chad Region: The Case of Boko Haram. Religions 11: 96. [CrossRef]

Mazerolle, Lorraine, Elizabeth Eggins, Adrian Cherney, Lorelei Hine, Angela Higginson, and Emma Belton. 2020. Police programmes that seek to increase community connectedness for reducing violent extremism behavior, attitudes and beliefs. Campbell Systematic Reviews 16: e1111.

Mbah, Peter, Chikodiri Nwangwu, and Herbert C. Edeh. 2017. Elite Politics and the Emergence of Boko Haram Insurgency in Nigeria. TRAMES: A Journal of the Humanities \& Social Sciences 2: 173-90.

McAdam, Doug. 2000. Culture and social movements. In Culture and Politics. New York: Palgrave Macmillan, pp. $253-68$. 
McCauley, Clark, and Sophia Moskalenko. 2008. Mechanisms of political radicalization: Pathways toward terrorism. Terrorism and Political Violence 20: 415-33. [CrossRef]

McCauley, Clark, and Sophia Moskalenko. 2017. Understanding political radicalization: The two-pyramids model. American Psychologist 72: 205. [CrossRef]

Mercy Corps. 2016. Motivations and Empty Promises: Voices of Former Boko Haram Combatants and Nigerian Youth. Available online: https://www.mercycorps.org/sites/default/files/Motivations\%20and\%20Empty\%20Promises_Mercy\%20Corps_Full \%20Report.pdf (accessed on 30 January 2021).

Michael Kpughe, L. 2017. Christian churches and the Boko Haram insurgency in Cameroon: Dilemmas and responses. Religions 8: 143. [CrossRef]

Mohammed, Kyari. 2018. The Origins of Boko Haram. In The Oxford Handbook of Nigerian Politics. London: Oxford University Press.

Mustapha, Abdul Raufu, ed. 2014. Sects E Social Disorder: Muslim Identities E Conflict in Northern Nigeria. Suffolk: Boydell \& Brewer Ltd.

Mythen, Gabe. 2020. Against the Odds? Unraveling the Paradoxes of Risk Prevention in Counter-Radicalization Strategy. In Criminal Justice, Risk and the Revolt against Uncertainty. Cham: Palgrave Macmillan, pp. 167-89.

Nduka, Cheijina. 2019. Boko Haram fighters paid \$3000 daily, says presidential committee. The Nation, April 30. Available online: https:/ / thenationonlineng.net/boko-haram-fighters-paid-3000-daily-says-presidential-committee/ (accessed on 7 August 2019).

Neumann, Peter R. 2003. The trouble with radicalization. International Affairs 89: 873-93. [CrossRef]

Neumann, Peter R. 2008. Joining al-Qaeda: Jihadist Recruitment in Europe. London: Routledge.

Neumann, Peter R., and Scott Kleinmann. 2013. How rigorous is radicalization research? Democracy and Security 9: 360-82. [CrossRef]

Nextier SPD. 2020a. Nigeria's Displacement Dilemma. Security, Peace, and Development Report. Abuja: Nextier SPD, June 11.

Nextier SPD. 2020b. Youths, COVID-19 and North-East Conflict. Security, Peace, and Development Report. Abuja: Nextier SPD, June 18.

Nnam, Macpherson U., Mercy Chioma Arua, and Mary Sorochi Otu. 2018. The use of women and children in suicide bombing by the Boko Haram terrorist Group in Nigeria. Aggression and Violent Behavior 42: 35-42. [CrossRef]

Nwammuo, Angela, and Abiodun Salawu. 2018. Are social media platforms not effective? Analysis of social movements for the release of Nigerian school girl Leah Sharibu abducted by Boko-Haram. African Journal of Peace and Conflict Studies 7: 95-119. [CrossRef]

Obamamoye, Babatunde F. 2018. Navigating the Enigma of Negotiating with a Jihadist Terrorist Group. African Security 11: $397-417$. [CrossRef]

Olarinmoye, Omobolaji Ololade. 2012. Faith-based organizations and development: Prospects and constraints. Transformation 29: 1-14. [CrossRef]

Olojo, Akinola E. 2013. Nigeria's troubled north: Interrogating the drivers of public support for Boko Haram. ICCT Research Paper, October 13. Available online: https://www.researchgate.net/profile/Akinola-Olojo-2/publication/335882365_Nigeria \T1 ttextq uoterights_Troubled_North_Interrogating_the_Drivers_of_Public_Support_for_Boko_Haram/links/5d81e82a299bf10c1ab5b 276/Nigerias-Troubled-North-Interrogating-the-Drivers-of-Public-Support-for-Boko-Haram.pdf (accessed on 8 September 2020).

Olojo, Akinola E. 2017. Resistance through Islamic clerics against Boko Haram in northern Nigeria. African Security Review 26: 308-24. [CrossRef]

Olojo, Akinola E. 2019. Dialogue with Boko Haram: Back on the Agenda? Africa Portal, July 4. Available online: https:/ /www.africapo rtal.org/features/dialogue-boko-haram-back-agenda/ (accessed on 14 October 2021).

Olojo, Akinola E. 2020. Making sense of resilience in the Boko Haram crisis. ISS West Africa Report 2020: 1-16.

Olson, Dean T. 2012. Tactical Counterterrorism: The Law Enforcement Manual of Terrorism Prevention. Springfield: Charles C Thomas Publisher.

Onapajo, Hakeem. 2017. Has Nigeria defeated Boko Haram? An appraisal of the counter-terrorism approach under the Buhari administration. Strategic Analysis 41: 61-73. [CrossRef]

Onapajo, Hakeem, and Abubakar A. Usman. 2015. Fuelling the flames: Boko Haram and deteriorating Christian-Muslim relations in Nigeria. Journal of Muslim Minority Affairs 35: 106-22. [CrossRef]

Onapajo, Hakeem, and Kemal Ozden. 2020. Non-military approach against terrorism in Nigeria: Deradicalization strategies and challenges in countering Boko Haram. Security Journal 33: 1-17. [CrossRef]

Onuoha, Freedom C. 2014. Why Do Youth Join Boko Haram? Washington, DC: US Institute of Peace.

Orji, Nkwachukwu. 2011. Faith-based aid to people affected by conflict in Jos, Nigeria: An analysis of the role of Christian and Muslim organizations. Journal of Refugee Studies 24: 473-92. [CrossRef]

Orsini, Alessandro. 2020. What Everybody Should Know about Radicalization and the DRIA Model. Studies in Conflict $\mathcal{E}$ Terrorism, 1-33. [CrossRef]

Osaghae, Eghosa E. 2017. Conflicts without borders: Fulani herdsmen and deadly ethnic riots in Nigeria. In The Fabric of Peace in Africa: Looking beyond the State. Montreal: McGill-Queen's Press-MQUP, pp. 49-66.

Ossai, Emmanuel Chiwetalu. 2021. 'I Respect My Imam, But I Can't Fight Even if He Tells Me to Fight. I am Peaceful for Myself and My Family': Are We Overestimating Religion in Peace Dynamics? Islam and Christian-Muslim Relations 32: 1-22. [CrossRef]

Ozer, Simon, and Preben Bertelsen. 2018. Capturing violent radicalization: Developing and validating scales measuring central aspects of radicalization. Scandinavian Journal of Psychology 59: 653-60. [CrossRef]

Payne, Laura. 2020. What Can Faith-Based Forms of Violent Conflict Prevention Teach Us About Liberal Peace? Religions 11: 167. [CrossRef] 
Peace Direct. 2016. Local Voices for Peace in Northern Nigeria: The Views of Local Civil Society on the Causes of Violent Conflict in the Region and the Prospects for Peace. Available online: https://www.peacedirect.org/wp-content/uploads/2016/11/Report-Ni geria-low-res-single-page.pdf (accessed on 18 November 2020).

Petersen, Marie Juul. 2015. For Humanity or for the Umma?: Aid and Islam in Transnational Muslim NGOs. Oxford: Oxford University Press.

Pettinger, Tom. 2017. De-radicalization and counter-radicalization: Valuable tools combating violent extremism, or harmful methods of subjugation? Journal for Deradicalization 12: 1-59.

Pieri, Zacharias P., and Jacob Zenn. 2016. The Boko Haram paradox: Ethnicity, religion, and historical memory in pursuit of a caliphate. African Security 9: 66-88. [CrossRef]

Pieri, Zacharias P., and Jacob Zenn. 2018. Under the Black Flag in Borno: Experiences o foot soldiers and civilians in Boko Haram's 'caliphate'. The Journal of Modern African Studies 56: 645-72. [CrossRef]

Pisoiu, Daniela. 2015. Subcultural theory applied to jihadi and right-wing radicalization in Germany. Terrorism and Political Violence 27: 9-28. [CrossRef]

Post, Jerrold M. 2007. The Mind of the Terrorist: The Psychology of Terrorism from the IRA to al-Qaeda. New York: St. Martin's Press.

Prud'homme, Joseph. 2019. Security, Religion, and Political Culture: A Defense of Weak Disestablishment. Religions 10: 88. [CrossRef]

Rascoff, Samuel J. 2012. Establishing Official Islam-The Law and Strategy of Counter-Radicalization. Stanford Law Review 64: 125.

Regens, James L., Nick Mould, Elizabeth Vernon, and Amanda Montgomery. 2016. Operational Dynamics of Boko Haram's Terrorist Campaign Following Leadership Succession. Social Science Quarterly 97: 44-52. [CrossRef]

Rink, Anselm, and Kunaal Sharma. 2018. The determinants of religious radicalization: Evidence from Kenya. Journal of Conflict Resolution 62: 1229-61. [CrossRef]

Rogers, Paul. 2012. Nigeria: The generic context of the Boko Haram violence. Monthly Global Security Briefing, 1-5.

Rubin, Lawrence, Rohan Gunaratna, and Jolene Jerard, eds. 2011. Terrorist Rehabilitation and Counter-Radicalisation: New Approaches to Counter-Terrorism. London: Routledge.

Sampson, Isaac Terwase. 2012. Religious violence in Nigeria: Causal diagnoses and strategic recommendations to the state and religious communities. African Journal on Conflict Resolution 12: 103-34.

Sampson, Isaac Terwase. 2016. The dilemmas of counter-bokoharamism: Debating state responses to Boko Haram terrorism in northern Nigeria. Security Journal 29: 122-46. [CrossRef]

Sedgwick, Mark. 2010. The concept of radicalization as a source of confusion. Terrorism and Political Violence 22: 479-94. [CrossRef]

Sikkens, Elga, Marion van San, Stijn Sieckelinck, Hennie Boeije, and Micha De Winter. 2017. Participant recruitment through social media: Lessons learned from a qualitative radicalization study using Facebook. Field Methods 29: 130-39. [CrossRef]

Silber, Mitchell D., Arvin Bhatt, and Senior Intelligence Analysts. 2007. Radicalization in the West: The Homegrown Threat; New York: Police Department, pp. 1-90.

Sivenbring, Jennie. 2019. Signs of concern about Islamic and right-wing extremism on a helpline against radicalization. Journal for Deradicalization. 18: 108-45.

Smith, Allison G. 2018. Risk Factors and Indicators Associated with Radicalization to Terrorism in the United States: What Research Sponsored by the National Institute of Justice Tells Us; Washington, DC: US Department Of Justice, Office of Justice Programs, National Institute of Justice, pp. 1-28.

Smith, Brent. 2008. A look at terrorist behavior: How they prepare, where they strike. NIJ Journal 260: 1-6.

Smith, Brent L., and Kelly R. Damphousse. 2009. Patterns of precursor behaviors in the life span of a US environmental terrorist group. Criminology \& Public Policy 8: 475-96.

Smith, Brent L., Jeff Gruenewald, Paxton Roberts, and Kelly R. Damphousse. 2015. The emergence of lone wolf terrorism: Patterns of behavior and implications for intervention. In Terrorism and Counterterrorism Today. Bingley: Emerald Group Publishing Limited.

Snow, David A., and Remy Cross. 2011. Radicalism within the context of social movements: Processes and types. Journal of Strategic Security 4: 115-30. [CrossRef]

Stephens, William, Stijn Sieckelinck, and Hans Boutellier. 2019. Preventing violent extremism: A review of the literature. Studies in Conflict $\mathcal{E}$ Terrorism 44: 1-16. [CrossRef]

Tella, Oluwaseun. 2018. Boko Haram terrorism and counter-terrorism: The soft power context. Journal of Asian and African Studies 53: 815-29. [CrossRef]

Thaut, Laura C. 2009. The role of faith in Christian faith-based humanitarian agencies: Constructing the taxonomy. Voluntas: International Journal of Voluntary and Nonprofit Organizations 20: 319-50. [CrossRef]

Thompson, Robin. 2011. Radicalization and the use of social media. Journal of Strategic Security 4: 167-90. [CrossRef]

Tomalin, Emma, ed. 2015. The Routledge Handbook of Religions and Global Development. London: Routledge.

Torregrosa, Javier, and Ángel Panizo. 2018. November. Risktrack: Assessing the risk of jihadi radicalization on twitter using linguistic factors. In International Conference on Intelligent Data Engineering and Automated Learning. Cham: Springer, pp. 15-20.

TRT World. 2018. Nigeria 'peace clubs' bid to counter Boko Haram propaganda. TRT World, October 13.

UNHCR. 2020. “Nigeria emergency”. The UN Refugee Agency. Available online: https://www.unhcr.org/nigeria-emergency.html (accessed on 13 December 2020). 
United Kingdom Prevent Duty Guidance. 2019. Statutory Guidance Revised Prevent Duty Guidance: For England and Wales. Available online: https://www.gov.uk/government/publications/prevent-duty-guidance/revised-prevent-duty-guidance-for-england -and-wales (accessed on 3 February 2021).

Uprety, Laya Prasad. 2009. Qualitative data collection, analysis and presentation: A theoretical overview. Dhaulagiri Journal of Sociology and Anthropology 3: 83-122. [CrossRef]

Van den Bos, Kees. 2018. Why People Radicalize: How Unfairness Judgments Are Used to Fuel Radical Beliefs, Extremist Behaviors, and Terrorism. Oxford: Oxford University Press.

Van den Bos, Kees. 2020. Unfairness and radicalization. Annual Review of Psychology 71: 563-88. [CrossRef] [PubMed]

Van Eerten, Jan-Jaap, Bertjan Doosje, Elly Konijn, B. A. de Graaf, and Mariëlle de Goede. 2017. Developing a Social Media Response to Radicalization: The Role of Counter-Narratives in Prevention of Radicalization and De-Radicalization, University of Amsterdam, Department of Psychology. Available online: https:/ / www.wodc.nl/onderzoeksdatabase/2607-effectiviteit-van-counternarrati ves.aspx?refTitle=rhOh-n_RA1rsAzOSCo9H7DBzPhYTfdGS1FErzBhlMIuiocdYMBelwNOmdZcnrUzeuzaXgKmsnEHR2wqw xqRqhrW-5WZ4hUNMTeLYDVzh0nSBS8-YXKIeIFne5Uwfeow0\&refId=SmyZrcVMoat3wpl4PoCqW0V8-zmc0W8pdsjKUxU iNkzk1A6TZP0dY4rskNd11LvoFYNr-sFkQINvJ7hhdUSrA2 (accessed on 15 October 2021).

Varaine, Simon. 2020. Revisiting the economics and terrorism nexus: Collective deprivation, ideology and domestic radicalization in the US (1948-2016). Journal of Quantitative Criminology 36: 667-99. [CrossRef]

Venhaus, John M. 2010. Looking for a Fight: Why Youth Join Al-Qaeda and How to Prevent It. Carlisle Barracks: Army War Coll.

Vergani, Matteo, Muhammad Iqbal, Ekin Ilbahar, and Greg Barton. 2020. The three Ps of radicalization: Push, pull and personal. A systematic scoping review of the scientific evidence about radicalization into violent extremism. Studies in Conflict $\mathcal{E}$ Terrorism 43 : $854-54$.

Vidino, Lorenzo. 2011. Countering Radicalization in America. Lessons from Europe; Special Report no. 262; Washington, DC: United States Institute of Peace, November.

Williams, Michael J. 2020. Preventing and Countering Violent Extremism: Designing and Evaluating Evidence-Based Programs. London: Routledge.

Wilner, Alex S., and Claire-Jehanne Dubouloz. 2010. Homegrown terrorism and transformative learning: An interdisciplinary approach to understanding radicalization. Global Change, Peace E Security 22: 33-51.

Wodu, Nkasi. 2020. 'Nigerian Security Forces and the Dangers of a Violence-First Approach'. Council on Foreign Relations, November 19. Available online: https://www.cfr.org/blog/nigerian-security-forces-and-dangers-violence-first-approach (accessed on 15 October 2021).

Zaidi, Manzar. 2010. A Link between Poverty \& Radicalization in Pakistan. Islamabad: Pakistan Institute for Peace Studies. 